YEARBOOK of ANTITRUST and REGULATORY STUDIES www.yars.wz.uw.edu.pl
Peer-reviewed scientific periodical, focusing on legal and economic issues of antitrust and regulation. Creative Commons Attribution-No Derivative Works 3.0 Poland License.

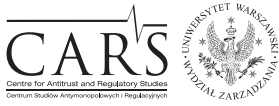

Centre for Antitrust and Regulatory Studies, University of Warsaw, Faculty of Management www.cars.wZ.uw.edu.pl

\title{
What Are the Directions in the Enforcement of Polish Competition Law - Review of a Series of New Polish Soft Law Guidelines
}

\author{
by
}

Anna Laszczyk*

\section{CONTENTS $^{* *}$}

I. Introduction

II. Newly adopted guidelines

1. Guidelines on contact with entrepreneurs

2. Guidelines on publishing the results of market inquiries

3. Guidelines on statements of objections

4. Guidelines on settlements

III. Updated soft law guidelines

1. Jurisdictional guidelines concerning concentration control

2. Guidelines on commitments decisions

3. Guidelines on the amount of fines imposed for competition restricting practices

IV. Conclusions

\section{Abstract}

A recent amendment to the Act of Competition and Consumer Protection of 2007, which entered into force in January 2015, brought with it a number of changes to the Polish competition law system introducing, among other things, several new legal institutions. This development created the need to issue new soft law guidelines in order to give some clarity as to their application. At the same time, certain pre-existing soft law guidelines of the Polish Competition Authority - the President of the UOKiK - needed updating in order to make them applicable to the new legal conditions. The aforementioned legislative changes were accompanied

* PhD candidate, Faculty of Law, University of Łódź, Associate at Linklaters C. Wiśniewski i Wspólnicy sp. k.; e-mail: anialaszczyk@gmail.com.

Article received: 18 March 2016; accepted: 18 July 2016. 
by an official UOKiK policy statement of openness and transparency. Given this objective, the UOKiK President provided a set of best practices for the Authority, in particular as regards its relations with undertakings. The aim of this paper is to critically review the newly adopted guidelines as well as modifications made to preexisting soft laws. It emerges from this analysis that although the issuance of any sort of guidelines should be welcomed in general, since it improves legal certainty as to the Authority's future conduct in individual cases, a number of problems remains which have not been sufficiently or in fact properly addressed.

\section{Resumé}

Une réforme récente de la Loi sur la concurrence et la protection des consommateurs de 2007, qui est entrée en vigueur en janvier 2015, a introduit un certain nombre de changements dans le système polonais du droit de la concurrence, $y$ compris des nouvelles institutions juridiques. Ce développement a créé un besoin de publier les lignes directrices afin de donner une certaine clarté concernant l'application des institutions juridiques qui ont été introduites. En même temps, certaines lignes directrices déjà publiés par l'autorité polonaise de la concurrence - le Président de l'UOKiK - devrait être mises à jour afin de les rendre applicables aux nouvelles conditions juridiques. Les changements législatifs mentionnés cidessus ont été accompagnés par la déclaration officielle de la part de UOKiK portant sur la politique d'ouverture et de transparence. Compte tenu de cet objectif, le Président d'UOKiK a fourni un code de bonnes pratiques pour l'Autorité de la concurrence, notamment en ce qui concerne ses relations avec les entreprises. Le but de cet article est d'examiner de manière critique les nouvelles lignes directrices adoptées par le Président d'UOKiK, ainsi que d'examiner des modifications apportées aux lignes directrices pré-existantes. Il ressort de cette analyse que, même si la publication de toute sorte de lignes directrices doit être appréciée, car elle améliore la sécurité juridique concernant la conduite future de l'Autorité de la concurrence dans des cas individuels, il reste toujours un certain nombre de problèmes qui n'étaient pas suffisamment ou correctement pris en compte.

Key words: soft law; guidelines; statement of objections; settlement; commitments.

JEL: K20

\section{Introduction}

2015 brought significant changes to Polish competition law. The key development took place via a substantial amendment (hereafter, Amendment) ${ }^{1}$ introduced to the Polish Act of Competition and Consumer Protection of

1 Act of 10 June 2014 amending the Act on Competition and Consumer Protection and the Civil Procedure Code (Journal of Laws 2014, item 945). 
2007 (hereafter, Competition Act) ${ }^{2}$. Among other things, the Amendment introduced two-phase merger control proceedings and novel procedures such as leniency plus and a settlement. These changes brought about the need to update pre-existing soft law guidelines applied by the President of the Polish Office of the Competition and Consumer Protection (hereafter, UOKiK or Authority). At the same time, the Amendment created the need to design and adopt a series of completely new soft law guidelines.

2015 was also noteworthy because of the policy of greater openness and transparency implemented by the UOKiK President. The Authority kept publicly emphasising that the relationship between the UOKiK and undertakings should be that of partnership that base their relations on mutual trust and respect. This new policy resulted in a number of soft law guidelines adopted in order to make the activities of UOKiK more transparent and predictable for undertakings.

The main aim of this paper is to critically review soft law guidelines adopted in this context and to assess, on this basis, the expected main directions of Polish competition law enforcement by the UOKiK. The analysis focuses on newly adopted soft law guidelines, but a short overview of changes made to pre-existing guidelines, that is those applied already before the Amendment entered into force, is also provided.

\section{Newly adopted soft law guidelines}

\section{Guidelines on contacting entrepreneurs with regard to the jurisdictional competence of the President of $\mathrm{UOKiK}^{3}$}

Shortly after the Amendment entered into force, the UOKiK published its Guidelines on contacting entrepreneurs with regard to the jurisdictional competence of the President of UOKiK (hereafter, Contact Guidelines). The Contact Guidelines are meant to fulfil the main principles of the Authority's declared policy, that is - openness and transparency. Under the new framework, the UOKiK intends to implement, as fully as possible, the following key principles of administrative procedure: deepening trust in public administration; active participation of undertakings in the proceedings as well as; accelerating and simplifying the proceedings. Hence, the UOKiK

2 Act of 16 February 2007 on Competition and Consumer Protection (Journal of Laws 2007, No 50, item 331).consolidated text

${ }^{3}$ Guidelines available at: https://uokik.gov.pl/download.php?plik=16154. 
emphasises that whenever it is reasonable, and does not encounter any legal or factual obstacles, an undertaking or an individual should have the right to be heard and to present his/her views concerning a case during an informal meeting with UOKiK representatives. An undertaking should also be given easy access to information and guidance of the Authority as to the legality of its market behaviour.

The Contact Guidelines describe various means of communication with the Authority (e-mail, phone calls, meeting). E-mails or phone calls may be used for seeking organisational, technical or rudimentary legal information. They would be particularly appropriate for: (i) seeking to clarify questions included in information requests sent by the UOKiK, (ii) obtaining basic information on documents included in a case file and on the status of the proceedings and their expected termination date, (iii) obtaining explanations with regard to provisions of the Competition Act concerning merger control. However, no information on the findings of the UOKiK made on the basis of evidence it collected would be passed on to undertakings.

The Contact Guidelines considers meetings (including informal hearings) as an efficient way for undertakings to pass on market information to the Authority in order to explain potentially complicated market interplays. When deciding whether conducting a meeting would be a reasonable option, the UOKiK analyses whether it would increase procedural efficiency. A meeting may serve: (i) to obtain information or get an early assessment of a leniency application (being considered by an undertaking, or which has already been submitted), (ii) to discuss potential competition concerns with regard to mergers, (iii) an undertaking to present its views on issues raised in ongoing proceedings. Minutes taken from such meetings are later included in the case file. Accordingly, any material used by an undertaking during a meeting can be included as well.

This new policy of the UOKiK should be assessed positively. Until now, the Authority was often criticised for its rather formalistic approach in this regard, which prevented undertakings from gaining a better understanding of on-going proceedings. In practice it was not unheard of the past for companies to only discover what exactly they were accused of (or objections to its planned concentration in merger control proceedings) when the antitrust decision was actually issued. The Contact Guidelines, which include practical examples, encourage undertakings to pro-actively seek contact with the UOKiK during antirust proceedings and, at the same time, give them a reasonable expectation to receive data which they request. It remains to be seen whether and how the new policy will be implemented in practice since it not only requires openness on the side of the Authority, but also confidence on the side of the undertakings that contacting the UOKiK would not prove detrimental to their position. 


\section{Guidelines on publishing the results of market inquiries ${ }^{4}$}

Another step in increasing administrative transparency is the UOKiK's declaration to publish the results of its market inquiries. When deciding on the form and scope of the publication of information on the results of a market inquiry, the Authority takes into account the educational value for consumers of a given inquiry, the scope of business secrets of undertakings questioned in the inquiry, and the scope of the information which needs to remain confidential, owing to the efficiency of ongoing proceedings. The Authority may publish the whole text of such a market report, its summary ${ }^{5}$ or only a press release. Alternatively, it can put the relevant data into a table or a presentation.

As with regard to the Contact Guidelines, introducing clear rules on publishing information on market inquiries is a positive step towards creating greater clarity as to the internal activities of the UOKiK.

\section{Guidelines on statements of objections}

The need to provide undertakings with detailed information on what charges are being raised against them by the UOKiK, which would include factual and legal reasons for instigating the proceedings, had been recognised long before the Amendment took shape. (Bernatt 2011, Bernatt 2012a, Bernatt $2012 \mathrm{~b})$. The UOKiK's earlier enforcement practice was far from satisfactory since situations occurred where a resolution of the opening of proceedings (hereafter, Resolution on the Institution of Proceedings) merely mirrored the wording of applicable legal proceedings ${ }^{6}$.

During the public consultations of the Amendment, the introduction of a mechanism analogous to EU statement of objections (hereafter, SO) was demanded by several stakeholders. It was argued that the scope of the Resolution on the Institution of Proceedings should be precisely determined in order to safeguard the procedural rights of the undertakings concerned. It was proposed that the said objectives could be achieved either through the imposition of a new duty upon the UOKiK to provide the undertakings concerned with information on the objections in the course of the proceedings, or through the determination of obligatory elements of the Resolution on

\footnotetext{
${ }^{4}$ Guidelines available at: https://uokik.gov.pl/download.php?plik=16154.

5 As it was recently done with a summary of the report on retail sales of pharmaceuticals by pharmacies which was published by the UOKiK in 2015 .

${ }^{6}$ Decision of the UOKiK President of 8 December 2009, DOK-7/2009.
} 
the Institution of Proceedings. The UOKiK rejected this proposal with the justification that it would require a substantial change of Polish antitrust procedure while Competition Policy for 2011-2013 did not point to the need to make such change. However, the Authority did not seem to dismiss the proposal in its entirety since it suggested that the introduction of a SO should be considered after the Amendment enters into force.

The position adopted by the UOKiK was criticised by both academics as well as legal practitioners. The need to provide undertakings with complete information on the charges facing them in the Resolution on the Institution of Proceedings is grounded in the general principle of administrative proceedings to give information to the parties, as well as in the provisions of the European Convention of Human Rights ${ }^{7}$ (Bernatt, Turno 2015). It was underlined that the absence of a SO significantly limits the right of defence of undertakings, since information on how the Authority assessed evidence, and how a given market behaviour was judged from an antitrust perspective, is usually only provided once the decision is actually issued (Gago and Rosiak 2013). Admittedly, at the final stage of the proceedings, before the decision is issued, an undertaking is granted the right to access the file, but in practice, at that late a stage of the proceedings, the case tends to be already decided.

Bearing in mind the above concerns, the step taken by the UOKiK to establish best practices of providing undertakings with a SO in its antitrust proceedings, as well as in proceedings on infringements of collective consumer interests, shall be assessed positively. The Authority committed itself to issue SO in Guidelines on providing investigated undertakings with 'a detailed justification of charges' (hereafter, SO Guidelines).

The introductory part of the SO Guidelines explains that the need to respect the principles of procedural fairness in the course of antitrust proceedings is the reason to introduce SO. Further on, the SO Guidelines also reveal that the introduction of $\mathrm{SO}$ responds to the proposals of competition law academics and practitioners.

The SO Guidelines envisage that a SO will be sent only if the UOKiK intends to issue a decision finding a practice which infringes competition/collective consumer interests, or imposing a fine for contradicting the provisions of the Competition Act. It follows from the above that a SO will not be issued if the UOKiK accepts commitments and issues a commitments decision, or if its proceedings are discontinued.

The Authority sends a SO once it collects all evidence because it is only at that time that the UOKiK can prepare a document containing an exhaustive

7 Also courts underline that standards derived from ECHR need to be respected - see judgment of SOKiK of 7 April 2004, XVII Ama 24/03, judgment of the Court of Appeals in Warsaw of 4 July 2012, VI Aca 202/12. 
legal and factual explanation of the charges raised against the investigated undertaking. In the SO, the UOKiK presents all relevant facts and evidence of the case (along with references to the case file) on which it will base its decision as well as the legal assessment of the established facts. The Authority also informs the undertaking whether it intends to impose a fine and lists applicable mitigating and aggravating factors - albeit it does not state what the exact amount of the fine will be. If applicable, a SO may also contain remedies, measures aimed at redressing lasting effects of the infringement (in case of an infringement of collective consumer interests) and information on an order of immediate enforceability.

A procedural party has fourteen days for commenting on the content of the $\mathrm{SO}$. If new circumstances or evidence appear after a SO is issued, the UOKiK sends an undertaking an amended SO.

The introduction of a SO shall be assessed positively as it provides undertakings with greater clarity in the course of antitrust proceedings. However, it should also be noted that a SO is not a decision or a resolution it is merely a letter of a preparatory character, issued before an administrative decision is rendered. Bearing in mind the character of a SO, and the fact that the SO Guidelines (like any other guidelines) are not binding, one may consider whether an undertaking is entitled to take any legal steps if the UOKiK either does not issue the SO or does not comply with its best practice established in the SO Guidelines. It seems that any claims in this context could be based directly on the provisions of the Competition Act in relation to the provisions of the Code of Administrative Procedure, and provisions of ECHR only. It would thus be reasonable for the current mechanism to have an only temporary character - to be used to observe how well it works in practice so as to improve its potential deficiencies. In the long term however, a specific obligation to issue SO should be introduced directly into the Competition Act.

\section{Guidelines on Settlements ${ }^{8}$}

The Amendment introduced a new mechanism into the Competition Act - a settlement procedure - which can be used if the Authority considers that a settlement would contribute to the acceleration of the proceedings. The settlement procedure can be applied by the UOKiK ex officio or upon a request of a procedural party. Undertakings and individuals are able to benefit from settlements and receive a fine reduction of $10 \%$ in comparison to the fine which they would have received without a settlement.

\footnotetext{
${ }^{8}$ Guidelines are available at: https://uokik.gov.pl/download.php?plik=16154.
} 
The Competition Act states that if a procedural party agrees to join the settlement procedure, the UOKiK informs it about its initial findings, the envisaged content of its decision, including the amount of the fine to be imposed as well as about the consequences of appealing against a settlement decision. The final statement encompasses an undertaking's declaration of a voluntary submission to the fine and the confirmation of: (i) the amount of fine accepted by that undertaking, (ii) being informed about the charges, (iii) being entitled to express its views on the case, (iv) being informed about the consequences of an appeal.

Both the procedural party concerned and the UOKiK are entitled to withdraw from an already opened settlement procedure but the Authority may do so only if it considers that a settlement would not contribute to accelerating the proceedings. Once a settlements procedure is discontinued, any information or evidence acquired by the UOKiK cannot be used in the proceedings in question or in any other proceedings.

The Settlements Guidelines clarify how a settlement is reached - they leave no doubts that accelerating proceedings is the sole condition taken into account by UOKiK when deciding if a settlement procedure is to be pursued. Given that the Authority is obliged to collect and analyse all evidence, unlike the EU and many national settlement procedures, Polish rules do not pursue the objective of simplifying the proceedings, as this would require the undertaking concerned to resign from its right to access the file or right to an oral hearing (Krajewska and Piszcz 2014). Accelerating proceedings is understood as terminating them without the necessity to defend a potential decision before the court as a result of an undertaking's appeal.

When considering whether a settlement would realise said objective in a given case, the UOKiK takes into account the probability to decide on a case within a reasonable timeframe, the nature of the infringement, the number of procedural parties, the scope of the factual circumstances of the case and the legal judgements questioned by the procedural parties. Refusal to commence a settlement procedure proposed by a party does not exclude initiating it by the UOKiK ex officio. The decision whether to approach a party with a settlement offer is made by the Authority once sufficient evidence to issue a decision is collected.

The Settlement Guidelines explicitly state that hybrid settlements are not excluded, although the objective of the discussed procedure is fully realised only if all procedural parties participate. A settlements procedure may be applied in proceedings based on leniency. In such cases, if a party does not benefit from full immunity, the amount of a fine already lowered as a result of a leniency application, is further lowered by the $10 \%$ associated with settlements. 
The Settlement Guidelines provide a detailed and practical description of the process of reaching a settlement. If the discussed procedure is initiated by the Authority, the latter sends a letter to all procedural parties and gives them 14 days to declare whether they are willing to join the procedure. If an undertaking submits a settlement request, the UOKiK responds within 14 days as to whether it accepts or rejects the offer. Reasons do not have to be given - be it by the undertaking requesting a settlement or by the Authority informing the parties that it wished to commence or refusing to commence a settlement procedure. A refusal to commence a settlement procedure cannot be appealed.

Once the procedure starts, the Authority informs undertakings about its initial findings in the proceedings. The scope of the information provided corresponds in principle to the information provided in a $\mathrm{SO}^{9}$, except for the fact that in the settlement procedure a party is also informed of the reasons and amount of the envisaged fine. A given undertaking does not receive information about findings concerning other procedural parties. One may consider here whether the Settlement Guidelines are not, in fact, inconsistent. They state, in one place, that to propose a settlement the UOKiK needs to have evidences sufficient to issue a decision. Yet in another place, they state that when offering a settlement the Authority shall present its 'initial findings'. However, one may interpret the use of the phrase 'initial findings' as meant to facilitate an exchange of views between the UOKiK and the undertakings concerned. In other words, 'initial findings' may suggest that the Authority is willing to discuss the case in order to reach a common understanding.

Once the said information is received, a party has 14 days to express its views. If it objects to the findings of the Authority, it should comment on the challenged circumstances and provide relevant evidence. It should also provide its own assessment of the circumstances influencing the amount of the fine, if these are also questioned. The UOKiK may modify its findings on the basis of the information received from such party, or it may reject its objections. An undertaking has another 14 days to present its position. After that the Authority provides its findings one more time and asks the party to submit its final position.

The Settlement Guidelines envisage an intensive exchange of views between the Authority and the undertakings concerned as to the evidence, the factual circumstances of the case, and their assessment. This is in line with a recent, and at the same time first, EU judgment on hybrid settlements where the General Court, elaborating on the essence of the settlement procedure, stated

9 In its recent judgement, the Court calls such case overview an advanced statement of objections - see T-456/10 Timab Industries and CieFinanciere et de Participations Roullier (CFPR), ECLI:EU:T:2015:296, para. 73. 
that: 'the Commission does not negotiate the question of the existence of an infringement of EU law or the appropriate penalty. However, that notice should not be an obstacle to discussions. The settlement procedure requires, by its very nature, an exchange of views between the parties. Accordingly, it is an inherent part of such a procedure that both the undertakings and the Commission should try to reach a common understanding of the situation'10. However one should agree that while reaching a common understanding of the situation, the UOKiK and the parties should as quickly as possible identify what the most controversial issues of the case are. By so doing, they can then tackle them within a reasonable amount of time rather than circumvent the objectives of the procedure (Krajewska and Piszcz, 2014)

Both the UOKiK and the undertakings are entitled to withdraw from the procedure at any time. Still, once the Authority receives the final statement from an undertaking it may do so only in specific situations justified by exceptional circumstances. Regrettably, the Settlements Guidelines do not give examples of such special cases.

Although in general a settlement procedure takes place in writing, the Settlements Guidelines mention a possibility of an undertaking meeting the UOKiK. In fact, such a meeting may also be initiated by the Authority itself. This is in line with the aforementioned openness and transparency policy pursued by the UOKiK. Such a possibility should be assessed positively because it may, at least partially, respond to the objections voiced towards the design on the Polish settlement procedure which, being merely written in nature, may weaken its main objective, namely accelerating antitrust proceedings (Krajewska, 2012)

The Settlements Guidelines also describe rules of using and giving access to documents and information submitted by procedural parties in the course of the settlement procedure. If the procedure is discontinued, none of the documents or information may be used in the proceedings in question, or in fact in any other proceedings. During the settlement procedure, access to documents and information may be given to other procedural parties only upon consent of the undertaking concerned. Such documents and data will never be accessed by $3^{\text {rd }}$ parties pursuant to the rules on access to public information.

The Settlement Guidelines provide desirable clarity as regards the operation of a new legal procedure. As it will be implemented in practice, it would be useful to update the guidelines with case law examples. In particular, further clarification is needed on the circumstances which allow the UOKiK to withdraw from a settlement procedure once an undertaking submits its final statement.

10 T-456/10 Timab Industries and CieFinanciere et de Participations Roullier (CFPR), para. 117. 


\section{Updated soft law guidelines}

Significant changes introduced in January 2015 to the Competition Act of 2007 made it necessary to also make relevant modifications to pre-existing soft law guidelines. Said modifications are briefly summarised below

\section{Jurisdictional guidelines concerning concentration control ${ }^{11}$}

The vast majority of the changes made to the Jurisdictional Guidelines adapt them to the new provisions of the Competition Act regarding, for instance, new exemptions from the duty to notify a concentration. They are also helpful in navigating the new notification form which was subject to several major modifications.

One of the most important novel clarifications concerns the creation of joint ventures. The Jurisdictional Guidelines draw a distinction between the 'creation of a joint venture' and the 'acquisition of control' in a situation when the target is an already existing and operating company belonging to the seller's capital group. If plans are for the target to substantially change or expand its business activities after the transaction, then the operation should be seen as a creation of a joint venture ${ }^{12}$. By contrast, if the scope of the target's activities is not to be significantly altered as a result of the transaction, then the operation should be qualified as an acquisition of control. Said distinction is of key importance for assessing the applicability of the exemption from the notification duty. A EUR 10 million threshold is applicable to the target only with regard to the acquisition of control. By contrast, when a joint venture is created, the turnovers of the parent companies need to be taken into account. The benefit of an exemption is thus far less likely in the latter case.

The Jurisdictional Guidelines also clarify what kind of actions can be taken by financial institutions in preparation for the sale of shares acquired on a temporary basis. Such temporary acquisitions benefit from a notification duty exemption, but there was uncertainty as to what actions a financial institution may take during the transitional period. The Guidelines now state that even exercising voting rights, if undertaken for the purpose of eliminating any obstacles as to the sale of shares, would not remove the benefit of such an exemption.

11 Guidelines are available at: https://uokik.gov.pl/download.php?plik=16154.

12 Also a significant change of the JV's activities shall be notified. 


\section{Guidelines on Commitments Decisions ${ }^{13}$}

Pursuant to the Competition Act the UOKiK President is authorised to issue a commitments decision when, on the basis of information coming from a complaint or evidence collected during explanatory proceedings, the Authority finds out that an infringement of competition law or collective consumers interests is plausible. In such cases, the UOKiK President accepts from the investigate undertakings commitments to undertake, or to discontinue given actions. The accepted commitments should result in the withdrawal from the potentially illegal practice and redress its negative market effects. When issuing a commitments decision, the UOKiK President does not impose a fine.

The Amendment enabled the UOKiK President to accept commitments even if a given practice, potentially incompatible with the provisions of the Competition Act, has already been discontinued.

The updated Guidelines on commitments decisions (Commitments Guidelines) take into account the aforementioned legislative changes and recent case law developments. They recognise commitments decision as a way of terminating proceedings by means of negotiations between the Authority and the undertakings concerned, which is clearly a sign of the new enforcement policy pursued by the UOKiK.

A commitments decision may be issued upon an undertaking's request when it offers commitments to change its market behaviour. Like in the previous version of the Commitments Guidelines, an undertaking is expected to offer commitments as soon as possible, preferably in response to the Resolution on the Institution of Proceedings. Commitments should be clear and precise enabling the UOKiK to verify their fulfilment. Yet when offering commitments, an undertaking should not only modify the questioned market behaviour, but also offer measures aimed at redressing its negative market effects. However, such a requirement is somewhat questionable. On the one hand, it should be assessed positively as it enables undertakings which already ceased a potentially illegal practice to benefit from a commitments decision. On the other hand, a redress duty may imply that a given practice is actually a breach of the Competition Act. Such contention would be incompatible with the assumption that in a commitments procedure the UOKiK does not prove, but only makes plausible the existence of an infringement. This is further confirmed by the fact that a commitments decision cannot be used before civil courts in private enforcement proceedings. The view should be supported that when offering commitments an undertaking is not obliged, and should not be expected, to acknowledge that its market behaviour may contradict the provisions of the Competition Act (Piszcz, 2012). In principle, a commitments decision should

13 Guidelines are available at: https://uokik.gov.pl/download.php?plik=16154. 
be regarded as a win-win solution - an undertaking is not found liable for an infringement but offers commitments which remedy plausible, but not proven concerns of the Authority.

The Commitments Guidelines give examples of possible redress mechanisms such as modifying the potentially anti-competitive or abusive practices, lowering prices, returning unduly collected fees, providing information required by relevant laws. Recent UOKiK decisions, where the Authority emphasised that redress is expected in particular in cases related to consumer protection, prove that commitments aimed at eliminating negative effects of the contested practice will be preferable. The Commitments Guidelines clarify that the recipient of a commitments decision cannot only commit to change its future behaviour; it is also expected to identify the negative effects of the contested practice in the past and undertake actions aimed at mitigating and/ or eliminating them.

When deciding on whether to accept commitments, the Authority will analyse whether a commitments decision would contribute to fulfilling two major aims underlying this procedure - accelerating proceedings and efficiency. The former is related to a quicker termination of proceedings thanks to liberating the UOKiK from the duty to collect all evidence and minimising the risk of judicial challenge. When analysing the efficiency criterion, the Authority will consider whether commitments would effectively redress the negatives consequences of a given practice on the market.

In principle commitments decision will not be issued in cases concerning hard-core restrictions owing to their largely negative effects on the market and unjustifiable benefits achieved by those engaging in such practices. In the view of the Authority, legal institutions such as leniency or leniency plus are better suited to be used with regard to hard-core restrictions. This limitation may raise concerns since the Competition Act does not restrict the use of commitments decision to selected infringements only. Neither do key criterions of applying a commitments decision justify said limitation. In principle, a presumption of quick and efficient proceedings may be equally applicable to hard-core restrictions. One may consider that de facto excluding the most serious of all antitrust infringements from the use of commitments decisions is meant to not hamper private enforcement. If, for instance, cartel members could avoid their antitrust liability by means of a commitments decision, potential private enforcement plaintiffs would be seriously impeded when seeking redress.

A novel measure applied in the Commitment Guidelines is the UOKiK's ability to market test commitments. However, such test has been used in practice already in the earlier $P G N I G$ case. Although the application of marketoriented measures should be welcomed, as it contributes to the achievement of efficiency objectives, one should be cautious here since excessively lengthy 
market tests may be counter-productive when it comes to the objective of accelerating antitrust proceedings. It would be desirable for the Guidelines to state in which circumstances would it be reasonable for the UOKiK to market-test commitments.

The Commitment Guidelines oblige the UOKiK to inform the undertaking concerned that the Authority has rejected its commitment offer before it issues its final decision. The Guidelines envisage that such rejection may incentivise an undertaking to cease the contested practice or to undertake redress measures. The UOKiK will then take into account such behaviour when setting the fines. It seems that the Guidelines are slightly overoptimistic in this regard, if not even irrational. From an undertaking's point of view, a rejection of its commitments offer implies that it would need to defend its position before the courts. In such a situation, ceasing the practice or providing redress would weaken its arguments.

The guidelines describe obligatory elements of a commitments decision: a statement of facts making an infringement plausible, the exact wording of the commitments, a duty to fulfil them and reporting obligations.

The Commitment Guidelines clarify also the conditions when an undertaking can expect to avoid a fine if it changes its behaviour and offers redress. The willingness of the UOKiK to talk with the undertaking about the scope of the commitments, even via informal meetings, and to apply market-oriented elements should be welcomed. However, the expectation to redress negative consequences of a given market practice would likely be very burdensome for some undertakings.

\section{Guidelines on the amount of fines imposed for competition restricting practices $^{14}$}

The Guidelines on the amount of fines imposed for competition restricting practices (hereafter, Fining Guidelines) have not been subject to major modifications. The most significant changes in this context pertain to amendments made to the Competition Act.

The updated Fining Guidelines retain the previous classification of infringements as: very serious, serious and other. What they do change is the qualification of so-called 'hub \& spoke arrangements' as very serious infringements.

With regards to aggravating and mitigating factors, the Fining Guidelines explain now that the list of mitigating factors is open. Undertakings are

${ }^{14}$ Guidelines are available at: https://uokik.gov.pl/download.php?plik=16154. 
therefore free to assert any circumstances which, in their view, may contribute to the lowering of their fine. The list of aggravating factors is on the other hand enumerative and so the Authority cannot invoke any other circumstances than those explicitly listed in the Fining Guidelines.

Furthermore, the list of mitigating factors was extended; it focuses on actions taken by an undertaking on its own initiative including, for instance, measures aimed at withdrawing from an infringement or redressing its effects. Co-operation with the Authority will be perceived as a mitigating factor only if it goes further than a simply fulfilment of an undertaking's obligation to provide information in response to an information request issued by the UOKiK.

As regards aggravating factors, the Fining Guidelines clarify now that the fact of committing an antitrust infringement in the past will influence the amount of the fine imposed for a new infringement in a proportionate manner to the level of similarity of the two breaches - the more similar the infringements, the bigger the increase in the fine will be.

The Fining Guidelines provide also some clarification with regard to the rules on the imposition of fines on undertakings achieving small turnovers as well as fines imposed on managers. As regards undertakings with small turnovers, the maximum fine which may be imposed by UOKiK is EUR 10,000 . When calculating fines, the Authority will generally follow its normal fining guidelines but, under certain circumstances, the fine may be altered to the maximum amount. This applies to situations when the turnover does not reflect the real economic potential of the undertaking, or the fine calculated pursuant to general fining principles would not serve its aim.

With regard to fines imposed on managers, the basis for calculating it is related to their income earned while working for the undertaking which committed the antitrust violation. The Guidelines contain a catalogue of mitigating and aggravating factors influencing the amount of fines imposed on managers, which is similar to those applicable to undertakings.

\section{Conclusions}

The number of guidelines adopted and modified after the major Amendment entered into force in January 2015 proves that the UOKiK reacted relatively swiftly to the new legal environment. This trend should be welcomed in general as it enables undertakings to better predict and prepare for the actions likely to be taken by the Authority in the course of its proceedings. The Contact Guidelines and the Market Inquiry Guidelines point to competition advocacy as a policy objective pursued by the UOKiK. It remains to be seen 
whether the new President UOKiK (appointed on 12 May 2016) will chose to follow this policy direction. The issuance of the SO Guidelines confirms that the principles of procedural fairness are to be recognised and respected by the Authority. However, procedural rights of undertakings would only be fully guaranteed if the duty to issue a SO was to be directly introduced into the Competition Act. The Commitments Guidelines and the Settlement Guidelines encourage undertakings to exchange views with the UOKiK as well as to submit their comments on the Authority's findings. They place the UOKiK and the undertakings in the position of negotiating partners as to the outcome of the proceedings. Here, once again, it remains to be seen whether such approach will be implemented in the future.

There is no doubt that the recent Amendment together with all the new soft law developments has equipped the UOKiK with a number of tools to be used in its competition law enforcement. Once they have been applied in practice, it would be useful for the Authority to supplement its guidelines with case law examples.

\section{References}

Bernatt, M. (2011). Sprawiedliwość proceduralna w postępowaniu przed organem ochrony konkurencji. Warszawa: Wydawnictwo Naukowe Wydziału Zarządzania UW.

Bernatt, M. (2012a). Ustawa o ochronie konkurencji I konsumentów - potrzeba nowelizacji. Perspektywa sprawiedliwości proceduralnej. internetowy Kwartalnik Antymonopolowy i Regulacyjny, 1(1), 85-96.

Bernatt, M. (2012b). Can the Right to Be Heard Respected without Access to Information about the Proceedings? Deficiencies of National Competition Procedure. YARS 5(6), 91-110.

Bernatt, M. and Turno, B. (2015). O potrzebie doskonalenia rozwiązań procesowych w znowelizowanej z dniem 18 stycznia 2015 r. ustawie o ochronie konkurencji i konsumentów. internetowy Kwartalnik Antymonopolowy i Regulacyjny, 2(4), 75-92.

Gago, R. and Rosiak, P.K. (2013). Uwagi dotyczące zakresu postanowienia o wszczęciu postępowania w świetle wymogu zapewnienia realizacji prawa do obrony oraz w związku z zakresem unijnego postanowienia o przedstawieniu zarzutów (Statement of objections), internetowy Kwartalnik Antymonopolowy i Regulacyjny, 7(2), 45-50.

Krajewska, E., (2012). Settlement w świetle doświadczeń europejskich - w poszukiwaniu najlepszych rozwiązań. internetowy Kwartalnik Antymonopolowy i Regulacyjny, 4(1), 57-76.

Krajewska, E., Piszcz, A. (2014). Komentarz do art. 89a. In: Skoczny, T. (ed.), Ustawa o ochronie konkurencji i konsumentów. Komentarz, p. 1099-1013, Warszawa: C.H. Beck. 